\title{
Synthesis of Glycerol-Derived 4-Alkyl-Substituted 1,2,3-Triazoles and Evaluation of Their Fungicidal, Phytotoxic, and Antiproliferative Activities
}

\author{
Adilson V. Costa, ${ }^{\oplus a}$ Luiza C. Moreira, ${ }^{a}$ Roberta T. Pinto, ${ }^{a}$ Thammyres A. Alves, ${ }^{b}$ \\ Vitor V. Schwan, ${ }^{b}$ Vagner T. de Queiroz, ${ }^{a}$ Milene M. Praça-Fontes, ${ }^{\odot b}$ \\ Róbson Ricardo Teixeira, ${ }^{\oplus *, c}$ Pedro A. B. Morais ${ }^{a}$ and Waldir C. de Jesus Júnior ${ }^{d}$ \\ ${ }^{a}$ Departamento de Química e Física, Universidade Federal do Espírito Santo, \\ Alto Universitário, s/n, Guararema, 29500-000 Alegre-ES, Brazil \\ ${ }^{b}$ Departamento de Biologia, Universidade Federal do Espírito Santo, \\ Alto Universitário, s/ $n$, Guararema, 29500-000 Alegre-ES, Brazil \\ ${ }^{c}$ Departamento de Química, Universidade Federal de Viçosa, \\ Av. P.H. Rolfs, s/n, 36570-900 Viçosa-MG, Brazil \\ ${ }^{d}$ Universidade Federal de São Carlos, Campus Lagoa do Sino, 18290-000 Buri-SP, Brazil
}

\begin{abstract}
Herein, the synthesis of nine novel glycerol-derived 4-alkyl-substituted 1,2,3-triazoles, using the $\mathrm{Cu}^{\mathrm{I}}$-catalyzed alkyne-azide cycloaddition reaction as the key step, is reported. The triazoles were characterized by infrared and nuclear magnetic resonance (NMR ${ }^{1} \mathrm{H}$ and ${ }^{13} \mathrm{C}$ ) spectroscopy and mass spectrometry. The nine prepared compounds were evaluated with regard to their phytotoxic, antiproliferative, and fungicidal activities. The fungicidal activity was assessed on Colletotrichum gloeosporioides, the causative agent of papaya anthracnose. All compounds presented high efficiency (comparable to the commercial fungicide tebuconazole) in inhibiting $C$. gloeosporioides sporulation. The phytotoxicity of the triazoles was assessed against Lactuca sativa. Germination was the less-affected parameter, whereas the most pronounced effects of the triazoles were on the germination speed index and root growth of the L. sativa seedlings. As indicators of antiproliferative activity, the mitotic index was evaluated along with chromosomal and nuclear alterations, all of which were influenced to different degrees by the triazoles. In addition, all derivatives demonstrated aneugenic and clastogenic actions in meristematic cells of $L$. sativa roots. Therefore, these 4-alkyl-substituted triazoles may represent a scaffold to be explored for the development of new fungicidal agents.
\end{abstract}

Keywords: 1,3-dipolar cycloaddition, 1,4-disubstituted 1,2,3-triazoles, click chemistry, antiproliferative activity, phytotoxicity, glycerol

\section{Introduction}

Heterocyclics are a group of structurally diverse compounds that play important roles in the pharmaceutical and agrochemical fields. ${ }^{1-3}$ The major classes of heterocyclic contain oxygen, sulfur, and nitrogen in their composition.

Among the several classes of heterocyclic, the 1,2,3-triazoles have received considerable attention from research groups. These five-membered scaffolds are exclusively synthetic in nature, and present a vast array of biological activities, including antibacterial, ${ }^{4-7}$ antifungal, ${ }^{8}$

*e-mail: robsonr.teixeira@ufv.br cytotoxic, ${ }^{9,10}$ antiviral, ${ }^{11,12}$ antimalaric, ${ }^{13,14}$ eishmanicidal, ${ }^{15}$ anticancerous, ${ }^{16,17}$ phytotoxic effects, ${ }^{18}$ among others. ${ }^{19,20}$ In addition, the monocyclic 1,2,3-triazoles and benzotriazoles present stability towards hydrolysis, oxidative/reductive conditions, and enzymatic degradation. ${ }^{21}$ Some unique features of the triazole compounds, such as their capabilities of hydrogen-bond formation and dipole-dipole and pistacking interactions, have increased their importance in the field of medicinal chemistry, as they bind to biological targets with high affinity owing to their improved solubility. ${ }^{20}$

Glycerol is a byproduct generated during the transesterification of vegetable oils and fats. It is an abundant natural polyol that exists in nature in the form 
of triacylglycerides. Since its discovery in 1779 , chemists have been finding applications for glycerol, which is used widely in the pharmaceutical and cosmetic industries. ${ }^{22,23}$ Other applications include its uses as a plasticizer in the polymer industry and as a moistening agent or solvent in the food industry. ${ }^{24}$ This compound has also found several applications as a building block for the construction of useful chemicals ${ }^{25-28}$ and as a medium for chemical reactions. ${ }^{29,30}$ Moreover, glycerol has been used for the preparation of bioactive compounds. ${ }^{31}$

In a previous investigation, ${ }^{32}$ we used glycerol as the starting material for the synthesis of triazolic derivatives presenting the general structure I (Figure 1), and assessed their fungicidal, phytotoxic, and cytotoxic activities. It was noticed that the biological activities of the derivatives I were significantly influenced by the nature of the $\mathrm{X}$ group attached to the triazole ring.

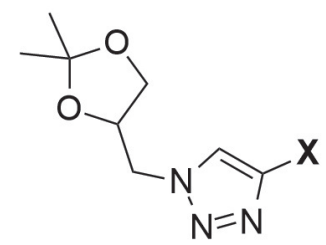

(I)

Figure 1. General structure of glycerol triazolic derivatives $\mathbf{I}$.

Previous reports in the literature have demonstrated the influence of alkyl groups in the biological response of bioactive substances. For example, 2,5-bis(alkylamino)1,4-benzoquinones present phytotoxic and cytotoxic effects that vary significantly with the size of the alkyl group. ${ }^{33,34}$ More recently, eugenol derivatives, containing different aliphatic chains with the parent molecule via an ether or ester linkage, were prepared and had their leishmanicide activity evaluated. From this investigation, a potent compound against visceral leihsmaniasis was found. ${ }^{35}$ It is important to mention that the variation of the length of alkyl group impact on solubility, increasing or decreasing partial atomic charge of pharmacophore site, and the total volume of resulting molecule. These, in turn, have a direct impact on bioactivity. The aforementioned precedents illustrate that variations of alkyl groups in a scaffold can result in the discovery of new compounds with significant bioactivities. Considering these facts and with the aim of obtaining compounds with improved biological activity based on scaffold $\mathbf{I}$, we have prepared novel glycerol derivatives bearing different alkyl substituents attached to the triazole functional group. The compounds were evaluated for their phytotoxic, antiproliferative, and fungicidal activities.

\section{Experimental}

\section{Generalities}

Terminal alkynes were purchased from Sigma-Aldrich (St. Louis, MO, USA) and used without further purification. The solvents and other reagents were procured from Vetec (Rio de Janeiro, Brazil) and used without further purification. The ${ }^{1} \mathrm{H}$ and ${ }^{13} \mathrm{C}$ nuclear magnetic resonance (NMR) spectra were recorded on a Varian Mercury 300 instrument (Varian, Palo Alto, CA, USA), at $300 \mathrm{MHz}$ for ${ }^{1} \mathrm{H}$ and $75 \mathrm{MHz}$ for ${ }^{13} \mathrm{C}$, using $\mathrm{CDCl}_{3}$ as the solvent and tetramethylsilane as the internal standard. The ${ }^{1} \mathrm{H}$ NMR data are presented as follows: chemical shift $(\delta)$ in ppm, multiplicity, the number of protons, and $J$ values in hertz $(\mathrm{Hz})$. Multiplicities are indicated by the following abbreviations: s (singlet), $\mathrm{d}$ (doublet), dd (double of doublets), t (triplet), q (quartet), quint (quintet), sept (septet), and $m$ (multiplet). The infrared (IR) spectra were acquired using a Tensor 27 device and the attenuated total reflection technique (ATR, Bruker, Karlsruhe, Germany), with scanning from 500 to $4000 \mathrm{~cm}^{-1}$. Melting points were determined using a MA 381 melting point apparatus (Marconi, São Paulo, Brazil), and are uncorrected. The progress of the reactions was monitored by thin-layer chromatography (TLC). Flash column chromatography was performed using a silica gel (70-230 mesh).

\section{Synthesis}

The compounds (2,2-dimethyl-1,3-dioxolan-4-yl) methanol (1), (2,2-dimethyl-1,3-dioxolan-4-yl)methyl4-methylbenzenesulfonate (2) and 4-(azidomethyl)2,2-dimethyl-1,3-dioxolane (3) were synthesized as previously described in the literature. ${ }^{32}$

\section{General procedure for the synthesis of triazoles $4 \mathbf{a}-\mathbf{4 i}$}

The azide 3 (1.00 g, $6.40 \mathrm{mmol})$, terminal alkyne ( $9.60 \mathrm{mmol})$, aqueous solution of tert-butyl alcohol $(6 \mathrm{~mL}$ of water and $6 \mathrm{~mL}$ of tert-butyl alcohol), $\mathrm{CuSO}_{4} \cdot 5 \mathrm{H}_{2} \mathrm{O}$ aqueous solution $\left(0.100 \mathrm{~mol} \mathrm{~L}^{-1}, 1.00 \mathrm{~mL}, 0.0960 \mathrm{mmol}\right)$, and sodium ascorbate $(0.0600 \mathrm{~g}, 0.288 \mathrm{mmol})$ were added to a round-bottomed flask and the reaction mixture was stirred at $50{ }^{\circ} \mathrm{C}$ for $8 \mathrm{~h}$. After the end of the reaction (verified by TLC analysis), distilled water $(10.0 \mathrm{~mL})$ was added and the aqueous layer was extracted with dichloromethane $(3 \times 20 \mathrm{~mL})$. The organic extracts were combined and the resulting organic phase was dried over anhydrous sodium sulfate, filtered, and concentrated under reduced pressure. The residue was purified by silica gel column chromatography, eluted with ethyl acetate-methanol 
$(9: 1 \mathrm{v} / \mathrm{v})$. The described procedure afforded triazoles $\mathbf{4 a}-\mathbf{4 i}$ in $65-84 \%$ yields. The structures of compounds $4 \mathbf{4}-4 \mathbf{i}$ were supported by the following data.

Synthesis of 1-((2,2-dimethyl-1,3-dioxolan-4-yl)methyl)4-propyl-1 $H$-1,2,3-triazole (4a)

Yellow liquid, prepared in $85 \%$ yield from the reaction between pent-1-yne (1.30 g, $19.2 \mathrm{mmmol})$ and azide 3 (2.00 g, $12.8 \mathrm{mmol})$; TLC (ether-dicloromethane 10:1 v/v) $\mathrm{Rf}=0.61$; IR (ATR) $\bar{v}_{\max } / \mathrm{cm}^{-1} 2984,1372,1216,1064$, 832, 798; ${ }^{1} \mathrm{H}$ NMR (300 MHz, $\left.\mathrm{CDCl}_{3}\right) \delta 0.93(\mathrm{t}, 3 \mathrm{H}$, $J 9.0 \mathrm{~Hz}$ ), 1.31 (s, 3H), 1.34 (s, 3H), 1.67 (sept, 2H, $J 9.0 \mathrm{~Hz}), 2.66(\mathrm{t}, 2 \mathrm{H}, J 9.0 \mathrm{~Hz}), 3.70(\mathrm{dd}, 1 \mathrm{H}, J 9.0,6.0 \mathrm{~Hz})$, 4.07 (dd, 1H, J 9.0, 6.0 Hz), 4.37 (dd, 1H, J 12.0, $6.0 \mathrm{~Hz}$ ), 4.40-4.45 (m, 1H), 4.48 (dd, 1H, J 12.0, 3.0 Hz), 7.38 (s, $1 \mathrm{H}) ;{ }^{13} \mathrm{C}$ NMR $\left(75 \mathrm{MHz}, \mathrm{CDCl}_{3}\right) \delta 14.0,22.9,25.4,26.8$, 27.8, 52.1, 66.6, 74.3, 110.2, 122.2, 148.3; MS ( $\mathrm{m} / \mathrm{z}, \%)$ $225\left(\left[\mathrm{M}^{+}\right], 4\right), 210\left([\mathrm{M}-15]^{+}, 3\right), 168(11), 167$ (46), 150 (13), 125 (13), 110 (50), 101 (30), 82 (1), 73 (27), 68 (35), 57 (57), 43 (100), 32 (17).

Synthesis of 1-((2,2-dimethyl-1,3-dioxolan-4-yl)methyl)4-butyl-1H-1,2,3-triazole (4b)

White solid, prepared in 93\% yield from the reaction between hex-1-yne (1.60 g, $19.2 \mathrm{mmmol})$ and azide 3 (2.00 g, $12.8 \mathrm{mmol}) ;$ TLC (ether-dichloromethane 10:1 v/v) $\mathrm{Rf}=0.60 ; \mathrm{mp} 52-53^{\circ} \mathrm{C}$; IR (ATR) $\bar{v}_{\max } / \mathrm{cm}^{-1} 3067,2927$, 1312, 1236, 1183, 1014, 844, 798, 648; ${ }^{1} \mathrm{H}$ NMR $(300 \mathrm{MHz}$, $\left.\mathrm{CDCl}_{3}\right) \delta 0.93(\mathrm{t}, 3 \mathrm{H}, J 9.0 \mathrm{~Hz}), 1.34(\mathrm{~s}, 3 \mathrm{H}), 1.37(\mathrm{~s}, 3 \mathrm{H})$, 1.38 (sept, $2 \mathrm{H}, J 9.0 \mathrm{~Hz}$ ), 1.68 (quint, $2 \mathrm{H}, J 9.0 \mathrm{~Hz}$ ), 2.71 (t, $2 \mathrm{H}, J 9.0 \mathrm{~Hz}), 3.77$ (dd, 1H, J 9.0, $6.0 \mathrm{~Hz}), 4.10(\mathrm{dd}$, $1 \mathrm{H}, J 9.0,6.0 \mathrm{~Hz}), 4.40(\mathrm{dd}, 1 \mathrm{H}, J 12.0,6.0 \mathrm{~Hz}), 4.40-$ $4.45(\mathrm{~m}, 1 \mathrm{H}), 4.51$ (dd, 1H, J 12.0, $6.0 \mathrm{~Hz}), 7.40$ (s, 1H); ${ }^{13} \mathrm{C} \mathrm{NMR}\left(75 \mathrm{MHz}, \mathrm{CDCl}_{3}\right) \delta 14.0,22.5,25.5,25.5,26.8$, 31.7, 52.2, 66.6, 74.4, 110.3, 122.1, 148.7; MS ( $\mathrm{m} / \mathrm{z}, \%)$ $239\left(\left[\mathrm{M}^{+}\right], 6\right), 124\left([\mathrm{M}-15]^{+}, 25\right), 224(40), 181(48), 164$ (11), 139 (16), 110 (66), 101 (38), 82 (27), 68 (41), 57 (74), 43 (100), 31 (10).

Synthesis of 1-((2,2-dimethyl-1,3-dioxolan-4-yl)methyl)4-pentyl-1 $\mathrm{H}$-1,2,3-triazole (4c)

White solid, prepared in $87 \%$ yield from the reaction between hep-1-yne (1.80 g, $19.2 \mathrm{mmmol})$ and azide $\mathbf{3}$ (2.00 g, $12.8 \mathrm{mmol}$ ); TLC (ether-dichloromethane 10:1 v/v)

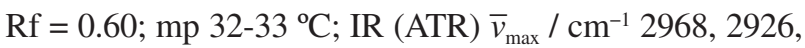
1380, 1269, 1204, 1062, 1032, 884, 836; ${ }^{1} \mathrm{H}$ NMR $(300 \mathrm{MHz}$, $\left.\mathrm{CDCl}_{3}\right) \delta 0.88$ (t, 3H, J 9.0 Hz), 1.33 (s, 3H), $1.36(\mathrm{~s}, 3 \mathrm{H})$, 1.37 (sept, 4H, $J 9.0 \mathrm{~Hz}$ ), 1.65 (quint, $2 \mathrm{H}, J 9.0 \mathrm{~Hz}$ ), 2.70 $(\mathrm{t}, 2 \mathrm{H}, J 9.0 \mathrm{~Hz}), 3.71(\mathrm{dd}, 1 \mathrm{H}, J 9.0,6.0 \mathrm{~Hz}), 4.09(\mathrm{dd}, 1 \mathrm{H}$, $J$ 9.0, $6.0 \mathrm{~Hz}$ ), 4.39 (dd, $1 \mathrm{H}, J$ 12.0, $9.0 \mathrm{~Hz}), 4.38-4.46$ (m, $1 \mathrm{H}), 4.50(\mathrm{dd}, 1 \mathrm{H}, J 12.0,9.0 \mathrm{~Hz}), 7.39(\mathrm{~s}, 1 \mathrm{H}) ;{ }^{13} \mathrm{C} \mathrm{NMR}$
(75 MHz, $\left.\mathrm{CDCl}_{3}\right) \delta 14.2,22.6,25.5,25.8,26.9,29.3,31.6$, $52.1,66.6,74.3,110.3,122.1,148.7 ; \mathrm{MS}(\mathrm{m} / z, \%) 253\left(\left[\mathrm{M}^{+}\right]\right.$, 12), 238 ([M - 15] $\left.]^{+}, 50\right), 195$ (47), 178 (11), 138 (27), 124 (69), 110 (36), 101 (49), 73 (30), 57 (73), 43 (100), 30 (10).

Synthesis of 1-((2,2-dimethyl-1,3-dioxolan-4-yl)methyl)4-hexyl-1 $H$-1,2,3-triazole (4d)

White solid, prepared in $75 \%$ yield from the reaction between oct-1-yne $(2.11 \mathrm{~g}, 19.2 \mathrm{mmmol})$ and azide $\mathbf{3}$ (2.00 g, $12.8 \mathrm{mmol}) ;$ TLC (ether-dichloromethane 10:1 v/v) $\mathrm{Rf}=0.68 ; \mathrm{mp} 58-60{ }^{\circ} \mathrm{C}$; IR (ATR) $\bar{v}_{\max } / \mathrm{cm}^{-1} 2871,1372$, 1216, 1147, 1076, 1014, 844, 798; 'H NMR (300 MHz, $\left.\mathrm{CDCl}_{3}\right) \delta 0.86(\mathrm{t}, 3 \mathrm{H}, J 9.0 \mathrm{~Hz}$ ), 1.30 (sept, $6 \mathrm{H}, J 9.0 \mathrm{~Hz}$ ), $1.33(\mathrm{~s}, 3 \mathrm{H}), 1.35(\mathrm{~s}, 3 \mathrm{H}), 1.64$ (quint, $2 \mathrm{H}, J 9.0 \mathrm{~Hz}), 2.69$ $(\mathrm{t}, 2 \mathrm{H}, J 9.0 \mathrm{~Hz}), 3.70(\mathrm{dd}, 1 \mathrm{H}, J 9.0,6.0 \mathrm{~Hz}), 4.07(\mathrm{dd}, 1 \mathrm{H}$, $J 9.0,6.0 \mathrm{~Hz}$ ), 4.37 (dd, $1 \mathrm{H}, J 12.0,6.0 \mathrm{~Hz}), 4.40-4.46(\mathrm{~m}$, $1 \mathrm{H}), 4.49(\mathrm{dd}, 1 \mathrm{H}, J 12.0,6.0 \mathrm{~Hz}), 7.39(\mathrm{~s}, 1 \mathrm{H}) ;{ }^{13} \mathrm{C} \mathrm{NMR}$ $\left(75 \mathrm{MHz}, \mathrm{CDCl}_{3}\right) \delta 14.2,22.7,25.4,25.8,26.8,29.1,29.6$, 31.7, 52.1, 66.6, 74.3, 110.3, 122.1, 148.6; MS $(\mathrm{m} / \mathrm{z}, \%)$ $267\left(\left[\mathrm{M}^{+}\right], 15\right), 252\left([\mathrm{M}-15]^{+}, 52\right), 209$ (40), $192(10)$, 168 (9), 152 (20), 138 (67), 124 (22), 101 (52), 96 (36), 68 (39), 57 (71), 43 (100), 30 (10).

Synthesis of 4-(1-((2,2-dimethyl-1,3-dioxolan-4-yl)methyl)4-(4-hydroxybutyl)-1 H-1,2,3-triazole (4e)

Yellow solid, prepared in $81 \%$ yield from the reaction between hex-5-yn-1-ol (1.40 g, $14.4 \mathrm{mmmol})$ and azide 3 (1.50 g, $9.60 \mathrm{mmol}) ;$ TLC (ether-dichloromethane 10:1 v/v) $\mathrm{Rf}=0.15 ; \mathrm{mp} 57-58^{\circ} \mathrm{C}$; IR (ATR) $\bar{v}_{\max } / \mathrm{cm}^{-1} 3450,3059$, 2933, 1269, 1203, 1051, 883, 837, 791; ' H NMR (300 MHz, $\left.\mathrm{CDCl}_{3}\right) \delta 1.32(\mathrm{~s}, 3 \mathrm{H}), 1.35$ (s, 3H), 1.61 (quint, $2 \mathrm{H}$, $J 12.0 \mathrm{~Hz}) 1.74$ (quint, $2 \mathrm{H}, J 9.0 \mathrm{~Hz}$ ), $2.41(\mathrm{~s}, 1 \mathrm{H}, \mathrm{OH}), 2.72$ $(\mathrm{t}, 2 \mathrm{H}, J 9.0 \mathrm{~Hz}), 3.66(\mathrm{dd}, 1 \mathrm{H}, J 9.0,6.0 \mathrm{~Hz}), 4.08(\mathrm{dd}, 1 \mathrm{H}$, $J$ 9.0, $6.0 \mathrm{~Hz}$ ), 4.34 (dd, $1 \mathrm{H}, J 12.0,6.0 \mathrm{~Hz}), 4.35-4.45$ (m, $1 \mathrm{H}), 4.48$ (dd, 1H, J 12.0, 6.0 Hz), 7.42 (s, 1H); ${ }^{13} \mathrm{C}$ NMR $\left(75 \mathrm{MHz}, \mathrm{CDCl}_{3}\right) \delta 25.2,25.5,26.6,32.1,52.0,62.1,66.4$,

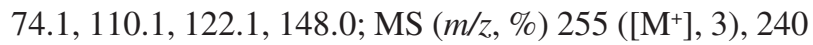
([M - 15] $\left.]^{+}, 8\right), 210$ (13), 197 (10), 126 (7), 101 (13), 69 (13), 57 (21), 43 (53), 32 (100).

Synthesis of 1-((2,2-dimethyl)1,3-dioxolan-4-yl)-4-heptyl$1 H-1,2,3$-triazole (4f)

White solid, prepared in $85 \%$ yield from the reaction between non-1-yne (1.78 g, $14.4 \mathrm{mmmol})$ and azide 3 $(1.50 \mathrm{~g}, 9.60 \mathrm{mmol}) ;$ TLC (ether-dichloromethane 10:1 v/v) $\mathrm{Rf}=0.68 ; \mathrm{mp} 45-47^{\circ} \mathrm{C}$; IR (ATR) $\bar{v}_{\max } / \mathrm{cm}^{-1} 2954,2919$, 2851, 2360, 1380, 1320, 1150, 1030, 924; ${ }^{1} \mathrm{H}$ NMR $\left(300 \mathrm{MHz}, \mathrm{CDCl}_{3}\right) \delta 0.85$ (t, 3H, J $9.0 \mathrm{~Hz}$ ), 1.29 (sept, $8 \mathrm{H}, J 9.0 \mathrm{~Hz}$ ), 1.33 (s, 3H), 1.35 (s, 3H), 1.64 (quint, $2 \mathrm{H}$, $J 9.0 \mathrm{~Hz}), 2.69(\mathrm{t}, 2 \mathrm{H}, J 9.0 \mathrm{~Hz}), 3.69(\mathrm{dd}, 1 \mathrm{H}, J 9.0,6.0 \mathrm{~Hz}$ ), 4.09 (dd, 1H, $J$ 9.0, $6.0 \mathrm{~Hz}), 4.32$ (dd, 1H, $J 12.0,6.0 \mathrm{~Hz}$ ), 
4.39-4.43 (m, 1H), $4.43(\mathrm{dd}, 1 \mathrm{H}, J$ 12.0, $6.0 \mathrm{~Hz}), 7.39$ (s, 1H); ${ }^{13} \mathrm{C}$ NMR $\left(75 \mathrm{MHz}, \mathrm{CDCl}_{3}\right) \delta 14.0,22.6,22.2,25.6,26.6$, 29.0, 29.1, 29.4, 31.7, 51.9, 66.4, 74.1, 110.0, 122.0, 148.5; MS (m/z, \%) $281\left(\left[\mathrm{M}^{+}\right], 13\right), 266$ ([M - 15] $\left.]^{+}, 44\right), 223(25)$, 210 (10), 197 (21), 166 (16), 152 (41), 138 (19), 124 (21), 110 (60), 101 (46), 82 (27), 68 (39), 57 (64), 43 (100), 30 (8).

Synthesis of 1-((2,2-dimethyl-1,3-dioxolan-4-yl)methyl)4-octyl-1H-1,2,3-triazole (4g)

White solid, prepared in $92 \%$ yield from the reaction between dec-1-yne (1.98 g, $14.4 \mathrm{mmmol})$ and azide 3 $(1.50 \mathrm{~g}, 9.60 \mathrm{mmol}) ; \mathrm{TLC}$ (ether-dichloromethane 10:1 v/v) $\mathrm{Rf}=0.69 ; \mathrm{mp} 64-65^{\circ} \mathrm{C}$; IR (ATR) $\bar{v}_{\max } / \mathrm{cm}^{-1} 2991,2949$, 2922, 2872, 2360, 1458, 1372, 1101, 844; ${ }^{1} \mathrm{H}$ NMR $\left(300 \mathrm{MHz}, \mathrm{CDCl}_{3}\right) \delta 0.85$ (t, 3H, J 9.0 Hz), 1.25 (sept, $10 \mathrm{H}, J 9.0 \mathrm{~Hz}), 1.31(\mathrm{~s}, 3 \mathrm{H}), 1.34(\mathrm{~s}, 3 \mathrm{H}), 1.63$ (quint, $2 \mathrm{H}$, $J 9.0 \mathrm{~Hz}), 2.68(\mathrm{t}, 2 \mathrm{H}, J 9.0 \mathrm{~Hz}), 3.70(\mathrm{dd}, 1 \mathrm{H}, J 9.0,6.0 \mathrm{~Hz})$, $4.08(\mathrm{dd}, 1 \mathrm{H}, J 9.0,6.0 \mathrm{~Hz}), 4.36(\mathrm{dd}, 1 \mathrm{H}, J 12.0,6.0 \mathrm{~Hz})$, 4.35-4.45 (m, 1H), 4.49 (dd, 1H, J 12.0, $6.0 \mathrm{~Hz}), 7.47$ (s, $1 \mathrm{H}) ;{ }^{13} \mathrm{C}$ NMR $\left(75 \mathrm{MHz}, \mathrm{CDCl}_{3}\right) \delta 14.0,22.6,25.2,25.6$, 26.6, 29.1, 29.2, 29.3, 29.4, 31.8, 51.9, 66.4, 74.1, 110.0, 121.9, 148.4; MS ( $\mathrm{m} / \mathrm{z}, \%) 295\left(\left[\mathrm{M}^{+}\right], 15\right), 280\left([\mathrm{M}-15]^{+}\right.$, 48), 237 (19), 210 (9), 197 (27), 180 (14), 166 (40), 138 (21), 124 (25), 110 (68), 101 (50), 82 (29), 68 (40), 57 (67), 43 (100), 32 (93).

Synthesis of 1-((2,2-dimethyl-1,3-dioxolan-4-yl)methyl)4-nonyl-1 $H$-1,2,3-triazole (4h)

White solid, prepared in $88 \%$ yield from the reaction between undec-1-yne $(0.500 \mathrm{~g}, 3.28 \mathrm{mmmol})$ and azide 3 $(0.562 \mathrm{~g}, 3.62 \mathrm{mmol})$; TLC (ether-dichloromethane $10: 1 \mathrm{v} / \mathrm{v}$ ) Rf $=0.69 ; \mathrm{mp} 55-57{ }^{\circ} \mathrm{C}$; IR (ATR) $\bar{v}_{\max } / \mathrm{cm}^{-1}$ 2922, 2852, 2360, 1507, 1307, 1258, 1184, 1076, 845; ${ }^{1} \mathrm{H}$ NMR $\left(300 \mathrm{MHz}, \mathrm{CDCl}_{3}\right) \delta 0.85(\mathrm{t}, 3 \mathrm{H}, J 9.0 \mathrm{~Hz}$ ), 1.25 (sext, 6H, $J 9.0 \mathrm{~Hz}$ ), 1.33 (s, 3H), 1.36 (s, 3H), 1.65 (quint, $2 \mathrm{H}, J 9.0 \mathrm{~Hz}), 2.69(\mathrm{t}, 2 \mathrm{H}, J 9.0 \mathrm{~Hz}), 3.71(\mathrm{dd}, 1 \mathrm{H}$, $J$ 9.0, $6.0 \mathrm{~Hz}), 4.09(\mathrm{dd}, 1 \mathrm{H}, J 9.0,6.0 \mathrm{~Hz}), 4.36(\mathrm{dd}, 1 \mathrm{H}$, $J$ 12.0, $6.0 \mathrm{~Hz}$ ), 4.42-4.45 (m, 1H), 4.46 (dd, 1H, $J$ 12.0, $6.0 \mathrm{~Hz}), 7.48(\mathrm{~s}, 1 \mathrm{H}) ;{ }^{13} \mathrm{C} \mathrm{NMR}\left(75 \mathrm{MHz}, \mathrm{CDCl}_{3}\right) \delta 14.0$, 22.6, 25.2, 25.6, 26.6, 29.1, 29.2, 29.3, 29.4, 31.8, 51.9, $66.4,74.1,110.0,121.9,148.4$; MS $(\mathrm{m} / z, \%) 309\left(\left[\mathrm{M}^{+}\right]\right.$, 16), 294 ([M - 15] $\left.]^{+}, 47\right), 251(14), 210$ (11), 197 (32), 180 (37), 166 (15), 152 (16), 138 (23), 124 (27), 110 (75), 96 (43), 68 (41), 57 (68), 43 (100), 32 (29).

Synthesis of 1-((2,2-dimethyl-1,3-dioxolan-4-yl)methyl)4-decyl-1H-1,2,3-triazole (4i)

White solid, prepared in $94 \%$ yield from the reaction between dodec-1-yne (2.39 g, $14.4 \mathrm{mmmol})$ and azide 3 $(1.50 \mathrm{~g}, 9.60 \mathrm{mmol})$; TLC (ether-dichloromethane 10:1 v/v) $\mathrm{Rf}=0.53 ; \mathrm{mp} 54-56{ }^{\circ} \mathrm{C}$; IR (ATR) $\bar{v}_{\max } / \mathrm{cm}^{-1} 3063,2954$,
2916, 2848, 2360, 1682, 1558, 1540, 1269, 1063, 837; ${ }^{1} \mathrm{H}$ NMR $\left(300 \mathrm{MHz}, \mathrm{CDCl}_{3}\right) \delta 0.85$ (t, 3H, $\left.J 9.0 \mathrm{~Hz}\right), 1.30$ (sext, 14H, J 9.0 Hz), 1.32 (s, 3H), 1.35 (s, 3H), 1.64 (quint, $2 \mathrm{H}, J 9.0 \mathrm{~Hz}), 2.68$ (t, $2 \mathrm{H}, J 9.0 \mathrm{~Hz}), 3.70(\mathrm{dd}, 1 \mathrm{H}, J 12.0$, $6.0 \mathrm{~Hz}$ ), 4.07 (dd, $1 \mathrm{H}, J 12.0,6.0 \mathrm{~Hz}), 4.35$ (dd, $1 \mathrm{H}, J$ 9.0, $6.0 \mathrm{~Hz}), 4.39-4.44(\mathrm{~m}, 1 \mathrm{H}), 4.45(\mathrm{dd}, 1 \mathrm{H}, J 9.0,6.0 \mathrm{~Hz})$, 7.39 (s, $1 \mathrm{H}) ;{ }^{13} \mathrm{C}$ NMR $\left(75 \mathrm{MHz}, \mathrm{CDCl}_{3}\right) \delta 14.0,22.6,25.2$, 25.6, 26.6, 29.1, 29.2, 29.3, 29.4, 29.5, 29.5, 31.8, 51.9, 66.4, 74.1, 110.0, 121.9, 148.4; MS ( $\mathrm{m} / \mathrm{z}, \%) 323\left(\left[\mathrm{M}^{+}\right], 3\right), 308$ ([M - 15] $\left.]^{+}, 9\right), 210$ (2), 194 (7), 168 (2), 152 (3), 138 (5), 124 (6), 110 (19), 96 (11), 69 (18), 57 (17), 44 (34), 32 (100).

\section{Evaluation of phytotoxic and antiproliferative activities}

Analyses of the compounds phytotoxic and antiproliferative activities were carried out on seeds of the $L$. sativa plant. ${ }^{32,36}$ The experiment was conducted in a completely randomized design, with nine treatments (4a-4i compounds), five concentrations (1, 10, 100, 500, and $1000 \mu \mathrm{g} \mathrm{m}^{-1}$ ), and four replicates each. The negative controls were distilled water and dichloromethane (DCM), and the positive control was the commercial herbicide picloram (1000 ppm).

Twenty-five lettuce seeds were placed in 9-cm-diameter Petri dishes containing a filter paper, and $2.5 \mathrm{~mL}$ of the test substances dissolved in DCM were subsequently added to the appropriately marked dishes. After sealing with film paper, the dishes were placed in a biochemical oxygen demand (BOD)-type germination chamber at room temperature $\left(24 \pm 2{ }^{\circ} \mathrm{C}\right)$. The percentage of germination $(\mathrm{G} \%)$ and germination speed index (GSI) were evaluated every $8 \mathrm{~h}$ for $48 \mathrm{~h}$. After $48 \mathrm{~h}$, the root length was measured for the indication of root growth (RG), as described by Pinheiro et al. ${ }^{37}$

To perform the microscopic analysis, ten roots from each Petri dish were collected after $48 \mathrm{~h}$ of treatment exposure, fixed in an ethanol-acetic solution $(3: 1 \mathrm{v} / \mathrm{v})$, and stored at $-4{ }^{\circ} \mathrm{C}$. The slides were prepared according to the squash technique and stained with $2 \%(\mathrm{v} / \mathrm{v})$ acetic orcein. After evaluation of the slides, the mitotic index (MI) and chromosomal alterations (CA\%) and nuclear alterations (NA\%) were determined.

The obtained data were submitted to analysis of variance and the means were analyzed using Dunnett's test $(p<0.05)$ to compare the treatments with the controls. ${ }^{38}$ All analyses were performed using the statistical analysis program GENES VS 2015.5.0. ${ }^{39}$

\section{Evaluation of fungicidal activity}

To evaluate the fungicidal effects of the triazoles $\mathbf{4 a} \mathbf{a}-\mathbf{4 i}$ 
on C. gloeosporioides, the experiment was conducted in a completely randomized design, with five replicates per treatment, consisting of each compound at the concentrations of $1,10,100,500$, and $1000 \mu \mathrm{g} \mathrm{mL} \mathrm{m}^{-1}$. The fungicide tebuconazole was used as a positive control and a solution of $3.5 \%(\mathrm{v} / \mathrm{v})$ dimethylsulfoxide (DMSO) as a negative control. The fungicides were incorporated into a potato-dextrose-agar (PDA) medium from aqueous solutions containing $3.5 \%(\mathrm{v} / \mathrm{v})$ DMSO and distributed in Petri dishes. The C. gloeosporioides isolate was obtained from tissues of damaged papaya fruits. Pure cultures were incubated in a PDA medium at $25^{\circ} \mathrm{C}$ for 10 days.

The fungicidal activity was determined according to the sensitivity of the $C$. gloeosporioides mycelial growth and sporulation to the treatments applied, according to the methodology described by Edgington et al. ${ }^{40}$ and Rampersad and Teelucksingh, ${ }^{41}$ with modifications. Discs with mycelia were placed in the center of the Petri dishes containing the different treatments. The plates were maintained at $25 \pm 1{ }^{\circ} \mathrm{C}$, with a photoperiod of $12 \mathrm{~h}$, and mycelial growth was estimated daily.

After the mycelial growth evaluation, a spore suspension was prepared for each treatment by adding distilled water $(10 \mathrm{~mL})$ to the Petri dishes. With the help of a Drigalski spatula, slight friction was applied to the fungal colonies to release the reproductive structures of the fungus into the culture medium. The obtained mixture was filtered through a gauze layer in a glass funnel. The suspension obtained was homogenized and the number of conidia in a Neubauer chamber was determined. The response variables were the percentage of inhibition of mycelial growth (PIMG) and percentage of inhibition of sporulation (PIS).

\section{Data analysis}

The data obtained for the PIMG and PIS variables were submitted to regression analysis and, through adjustments of the inhibition curves, the $\mathrm{ED}_{50}$ and $\mathrm{ED}_{100}$ values (concentration of the active ingredient of the fungicide necessary to inhibit 50 and $100 \%$ of the mycelial growth and sporulation of the pathogen) were obtained. The analyses were made with the software R (R Core Team 2013) and Polo-PC. ${ }^{42}$

After the $\mathrm{ED}_{50}$ calculation, the fungicides were grouped according to their efficiency, and the C. gloeosporioides isolate was rated for its sensitivity toward the fungicides according to the scale of Edgington et al. ${ }^{40}$ as follows: (i) $\mathrm{ED}_{50}<1$ ppm: high efficiency (HE) or high sensitivity (HS); (ii) $\mathrm{ED}_{50}$ 1-10 ppm: moderate efficiency (ME) or moderate sensitivity (MS); (iii) $\mathrm{ED}_{50} 10-50 \mathrm{ppm}$ : low efficiency (LE) or low sensitivity (LS); and (iv) $\mathrm{ED}_{50}>50$ ppm: not efficient (NE) or not sensitive (NS).

\section{Results and Discussion}

\section{Synthesis of glycerol derivatives}

The reactions used for the preparation of triazoles $\mathbf{4 a}$ 4i are outlined in Scheme 1. As indicated in Scheme 1, glycerol was converted to acetonide (1) using standard methodology. Then, treatment of compound $\mathbf{1}$ with tosyl chloride produced the sulfonate ester (2) in 75\% yield. The $\mathrm{S}_{\mathrm{N}} 2$ reaction between 2 and sodium azide afforded $\mathbf{3}$ in $93 \%$ yield. Finally, the $\mathrm{Cu}^{\mathrm{I}}$-catalyzed alkyne-azide cycloaddition reaction (CuAAC reaction, also known as the click reaction) between azide (3) and different aliphatic terminal alkynes resulted in the formation of triazoles $\mathbf{4 a - 4 i}$ in $75-93 \%$ yields (Scheme 1).

The structures of the triazolic derivatives $\mathbf{4 a - 4 i}$ were confirmed upon IR and ${ }^{1} \mathrm{H}$ and ${ }^{13} \mathrm{C}$ NMR spectroscopy as well as mass spectrometry analyses. In the IR spectra, the band corresponding to the $=\mathrm{C}-\mathrm{H}$ stretching was observed within the $3063-3083 \mathrm{~cm}^{-1}$ range. In the ${ }^{1} \mathrm{H}$ NMR spectra, signals corresponding to the hydrogens of the triazole rings and acetonide methyl groups were observed within the 7.38-7.48 and 1.31-1.37 ppm ranges, respectively. In the ${ }^{13} \mathrm{C}$ NMR spectra, signals for the acetonide methyl groups were observed within 25.2-26.8 ppm, whereas the carbons of the triazolic moiety appeared at $121.9-148.7 \mathrm{ppm}$. The molecular formulas for the triazolic derivatives were confirmed on the basis of the mass spectrometry results.

\section{Biological evaluation}

With compounds $\mathbf{4 a}-\mathbf{4 i}$ in hand, we turned our attention to the evaluation of their phytotoxic, antiproliferative, and fungicidal activities. In the phytotoxic evaluation (Table 1), the parameter least affected by the nine triazolic derivatives was the germination of Lactuca sativa. The treatment effects were statistically similar to those of the negative controls (water and DCM), except for the $1000 \mu \mathrm{g} \mathrm{mL}^{-1} \mathbf{4 c}$ treatment, which caused a $35 \%$ reduction in germination. This parameter seems to be the least sensitive of the variables evaluated in macroscopic tests. ${ }^{43}$

The most pronounced effects of the triazolic derivatives were observed on the GSI and RG of $L$. sativa seedlings. The derivatives $\mathbf{4 a}, \mathbf{4 b}, \mathbf{4 c}, \mathbf{4 d}, \mathbf{4 f}$, and $\mathbf{4 h}$ influenced the reduction of the presented GSI and RG means, especially at the higher concentrations (500 and $1000 \mu \mathrm{g} \mathrm{mL}^{-1}$ ). In addition, for derivative $\mathbf{4 c}$ at the concentration of $1000 \mu \mathrm{g} \mathrm{mL}^{-1}$, the 68.53 and $85.78 \%$ reduction in GSI and 
<smiles>OCC(O)CO</smiles>

Glycerol



$24 \mathrm{~h}$<smiles>CC1(C)OCC(CO)O1</smiles>

(1)<smiles></smiles>

(2)<smiles>[R]c1cn(CC2COC(C)(C)O2)nn1</smiles>

$(4 a-4 j)$

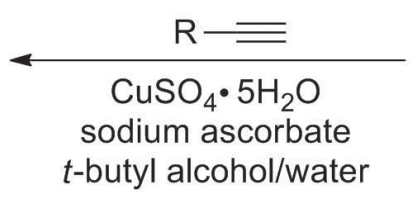

(3)
4a: $\mathrm{R}=\mathrm{CH}_{3} \mathrm{CH}_{2} \mathrm{CH}_{2}-$
4b: $\mathrm{R}=\mathrm{CH}_{3}\left[\mathrm{CH}_{2}\right]_{2} \mathrm{CH}_{2}-$
4c: $\mathrm{R}=\mathrm{CH}_{3}\left[\mathrm{CH}_{2}\right]_{3} \mathrm{CH}_{2}-$
4d: $\mathrm{R}=\mathrm{CH}_{3}\left[\mathrm{CH}_{2}\right]_{4} \mathrm{CH}_{2}$ -
4e: $\mathrm{R}=\mathrm{HOCH}_{2} \mathrm{CH}_{2} \mathrm{CH}_{2} \mathrm{CH}_{2}-$
4f: $\mathrm{R}=\mathrm{CH}_{3}\left[\mathrm{CH}_{2}\right]_{5} \mathrm{CH}_{2}-$
4g: $\mathrm{R}=\mathrm{CH}_{3}\left[\mathrm{CH}_{2}\right]_{6} \mathrm{CH}_{2}-$
4h: $\mathrm{R}=\mathrm{CH}_{3}\left[\mathrm{CH}_{2}\right]_{7} \mathrm{CH}_{2}$
4i: $\mathrm{R}=\mathrm{CH}_{3}\left[\mathrm{CH}_{2}\right]_{8} \mathrm{CH}_{2}-$

Scheme 1. Synthesis of 1,2,3-triazoles 4a-4i. Glycerol was used as the starting material for preparation of the new triazolic derivatives. Intermediates $\mathbf{1}$, $\mathbf{2}$ and $\mathbf{3}$ were obtained in 63, 75 and 93\% yields, respectively. Compounds $\mathbf{4 a - 4 i}$ were obtained in $75-94 \%$ yields.

RG values, respectively, were statistically similar to those of the positive control.

Derivative $4 \mathbf{e}$ at the concentrations of 500 and $1000 \mu \mathrm{g} \mathrm{mL}^{-1}$ increased the RG means of the L. sativa seeds, showing statistically significant differences compared with the positive and negative controls. This increase may have been due to the cellular elongation that occurs in the processes of growth and differentiation. ${ }^{44}$ Among several other processes, cellular differentiation is dependent on the activity of enzymes acting on cell expansion, cell wall remodeling, and cellulose deposition, linked to turgescence, via water absorption. ${ }^{45}$ It is possible that some of these factors were influenced by the action of $\mathbf{4 e}$.

Costa et al. ${ }^{32}$ evaluated the effects of other glycerolderived triazoles on $L$. sativa. However, the authors did not observe any influence of the derivatives on macroscopic parameters as compared with a negative control, suggesting that the action of the triazoles may be related to the photosynthetic process. Borgati et al..$^{18}$ evaluated triazolic derivatives containing halogenated benzyl groups and compared their reduction of RG in onion (Allium cepa, another widely used species in phytotoxic bioassays) with that by 2,4-dichlorophenoxyacetic acid (a commercial herbicide popularly known as 2,4-D).

The phytotoxicity of a compound is directly related to its antiproliferative activity. ${ }^{32}$ This relationship can be visualized through microscopic analysis and cell cycle evaluation of the meristematic cells. In the present study, the mitotic index (MI) was evaluated, as well as the frequencies of chromosomal alteration (CA) and nuclear alteration (NA). The MI was reduced in the meristematic cells of lettuce roots treated with $4 \mathbf{a}\left(100,500\right.$ and $\left.1000 \mu \mathrm{g} \mathrm{m}^{-1}\right)$, 4b $\left(1000 \mu \mathrm{g} \mathrm{mL} L^{-1}\right), 4 \mathbf{c}\left(1000 \mu \mathrm{g} \mathrm{mL}^{-1}\right), 4 \mathbf{d}(500$ and $\left.1000 \mu \mathrm{g} \mathrm{mL}^{-1}\right), 4 \mathrm{e}\left(500\right.$ and $\left.1000 \mu \mathrm{g} \mathrm{mL}^{-1}\right), \mathbf{4 f}(100,500$ and $\left.1000 \mu \mathrm{g} \mathrm{mL}^{-1}\right)$, and $\mathbf{4 h}\left(500\right.$ and $\left.1000 \mu \mathrm{g} \mathrm{mL}^{-1}\right)$, with the last compound being the most repressive, resulting in an $\mathrm{MI}$ reduction of $46.27 \%$ relative to the control (water) value. The MI reduction is an indication of events blocking 
Table 1. Macroscopic and microscopic parameters evaluated in Lactuca sativa seeds and root meristems treated with triazoles $\mathbf{4 a - 4 i}$ at five different concentrations. The positive control was the herbicide picloram, whereas the negative controls were distilled water and dichloromethane (DCM)

\begin{tabular}{|c|c|c|c|c|c|c|c|}
\hline Compound & $\begin{array}{c}\text { Concentration / } \\
\left.(\mu \mathrm{g} \mathrm{mL})^{-1}\right)\end{array}$ & $\mathrm{G} / \%$ & GSI & $\mathrm{RG}$ & $\mathrm{IM} / \%$ & NA / $\%$ & $\mathrm{CA} / \%$ \\
\hline \multirow{5}{*}{$4 a$} & 1000 & $93 \mathrm{ab}$ & 7.66 & 7.88 & 7.13 & 1.77 & 2.7333 \\
\hline & 500 & $92 \mathrm{ab}$ & 9.38 & 9.39 & 8.82 & $0.97 \mathrm{ab}$ & 3.03 \\
\hline & 100 & $97 \mathrm{ab}$ & $10.80 \mathrm{ab}$ & $13.40 \mathrm{ab}$ & 8.92 & $0.57 \mathrm{ab}$ & 2.4633 \\
\hline & 10 & $98 \mathrm{ab}$ & $11.56 \mathrm{ab}$ & $12.83 \mathrm{ab}$ & $12.44 \mathrm{ab}$ & $0.50 \mathrm{ab}$ & 3.69 \\
\hline & 1 & $99 \mathrm{ab}$ & $10.74 \mathrm{ab}$ & $12.46 \mathrm{ab}$ & 14.67 & $0.27 \mathrm{ab}$ & 3.1 \\
\hline \multirow{5}{*}{$4 b$} & 1000 & 80 & 6.34 & 4.51 & 8.34 & $1.03 \mathrm{ab}$ & 2.1667 \\
\hline & 500 & $90 \mathrm{ab}$ & 7.25 & 5.18 & 10.96ab & $0.56 \mathrm{ab}$ & 2.4633 \\
\hline & 100 & $97 \mathrm{ab}$ & $10.46 \mathrm{~b}$ & 9.63 & $12.69 \mathrm{ab}$ & $0.67 a b$ & 2.9633 \\
\hline & 10 & $95 \mathrm{ab}$ & $11.03 \mathrm{ab}$ & $11.37 \mathrm{ab}$ & $12.04 \mathrm{ab}$ & $0.53 \mathrm{ab}$ & 2.8367 \\
\hline & 1 & $98 \mathrm{ab}$ & $11.42 \mathrm{ab}$ & $11.58 \mathrm{ab}$ & 14.15 & $0.27 \mathrm{ab}$ & 2.3267 \\
\hline \multirow{5}{*}{$4 \mathrm{c}$} & 1000 & $65 \mathrm{c}$ & $3.81 \mathrm{c}$ & $1.85 \mathrm{c}$ & 7.35 & $1.16 \mathrm{~b}$ & $1.8333 \mathrm{~b}$ \\
\hline & 500 & $90 \mathrm{ab}$ & 7.26 & 4.55 & $9.51 \mathrm{a}$ & $1.20 \mathrm{~b}$ & 2.1333 \\
\hline & 100 & $97 \mathrm{ab}$ & $10.60 \mathrm{ab}$ & 6.88 & $10.30 \mathrm{ab}$ & $0.90 \mathrm{ab}$ & $1.7267 b$ \\
\hline & 10 & $96 a b$ & 10.86ab & 9.65 & 13.40 & $0.27 a b$ & $1.5333 b c$ \\
\hline & 1 & $98 \mathrm{ab}$ & $11.57 \mathrm{ab}$ & $13.68 \mathrm{~b}$ & 16.13 & $0.10 \mathrm{ab}$ & $1.7667 \mathrm{~b}$ \\
\hline \multirow{5}{*}{$4 d$} & 1000 & 86 & 5.73 & 3.23 & 6.07 & $1.27 \mathrm{~b}$ & $1.3667 \mathrm{abc}$ \\
\hline & 500 & $89 \mathrm{ab}$ & 7.57 & 4.69 & $10.08 \mathrm{ab}$ & $0.80 \mathrm{ab}$ & 2.3233 \\
\hline & 100 & $96 a b$ & $10.54 b$ & 6.95 & 11.96ab & $0.43 a b$ & 1.9967 \\
\hline & 10 & $98 \mathrm{ab}$ & $11.38 \mathrm{ab}$ & 9.68 & 14.39 & $0.17 \mathrm{ab}$ & $1.8967 \mathrm{~b}$ \\
\hline & 1 & $97 \mathrm{ab}$ & $10.81 \mathrm{ab}$ & $11.71 \mathrm{ab}$ & 18.06 & $0.00 \mathrm{ab}$ & 2.2333 \\
\hline \multirow{5}{*}{$4 e$} & 1000 & $100 \mathrm{ab}$ & $11.02 \mathrm{ab}$ & 15.40 & $9.53 \mathrm{a}$ & $0.30 \mathrm{ab}$ & $1.7333 b$ \\
\hline & 500 & $95 \mathrm{ab}$ & $11.10 \mathrm{ab}$ & 15.79 & $12.46 \mathrm{ab}$ & $0.20 \mathrm{ab}$ & $1.6667 \mathrm{~b}$ \\
\hline & 100 & $97 \mathrm{ab}$ & 11.67ab & $13.77 \mathrm{~b}$ & $12.89 \mathrm{ab}$ & $0.00 \mathrm{ab}$ & $1.5333 b c$ \\
\hline & 10 & $97 \mathrm{ab}$ & $10.97 \mathrm{ab}$ & $13.36 \mathrm{ab}$ & 13.73 & $0.30 \mathrm{ab}$ & $1.1667 \mathrm{abc}$ \\
\hline & 1 & $99 \mathrm{ab}$ & $11.71 \mathrm{ab}$ & $12.67 \mathrm{ab}$ & 15.03 & $0.10 \mathrm{ab}$ & $0.9333 \mathrm{abc}$ \\
\hline \multirow{5}{*}{ 4f } & 1000 & 87 & 6.65 & 4.65 & 7.24 & $0.00 \mathrm{ab}$ & $0.7667 \mathrm{abc}$ \\
\hline & 500 & $92 \mathrm{ab}$ & 6.81 & 4.75 & 8.49 & $0.00 \mathrm{ab}$ & $0.6333 \mathrm{abc}$ \\
\hline & 100 & $97 \mathrm{ab}$ & $10.65 \mathrm{ab}$ & 6.93 & $10.57 \mathrm{ab}$ & $0.00 \mathrm{ab}$ & $1.0633 \mathrm{abc}$ \\
\hline & 10 & $98 \mathrm{ab}$ & 11.73ab & $10.39 \mathrm{a}$ & 14.46 & $0.00 \mathrm{ab}$ & $1.2933 \mathrm{abc}$ \\
\hline & 1 & $97 \mathrm{ab}$ & $12.02 \mathrm{ab}$ & $11.19 \mathrm{a}$ & 16.92 & $0.00 \mathrm{ab}$ & $1.3633 \mathrm{abc}$ \\
\hline \multirow{5}{*}{$4 g$} & 1000 & $97 \mathrm{ab}$ & 11.04ab & 8.56 & 8.70 & $0.23 \mathrm{ab}$ & $0.7333 \mathrm{abc}$ \\
\hline & 500 & $96 a b$ & $10.97 \mathrm{ab}$ & 9.34 & 9.17 & $0.07 \mathrm{ab}$ & $0.6333 \mathrm{abc}$ \\
\hline & 100 & $98 \mathrm{ab}$ & 11.37ab & 10.05 & 8.68 & $0.00 \mathrm{ab}$ & $0.6633 \mathrm{abc}$ \\
\hline & 10 & $99 \mathrm{ab}$ & $11.88 \mathrm{ab}$ & $11.53 \mathrm{ab}$ & $10.78 \mathrm{ab}$ & $0.07 \mathrm{ab}$ & $0.7333 \mathrm{abc}$ \\
\hline & 1 & $100 \mathrm{ab}$ & 12.18ab & 12.61ab & 13.83 & $0.00 \mathrm{ab}$ & $0.6667 \mathrm{abc}$ \\
\hline \multirow{5}{*}{$4 h$} & 1000 & $96 a b$ & 8.73 & 6.53 & 6.05 & $0.37 \mathrm{ab}$ & $0.4033 \mathrm{abc}$ \\
\hline & 500 & $98 \mathrm{ab}$ & 9.28 & 7.58 & 7.14 & $0.86 a b$ & $0.6633 \mathrm{abc}$ \\
\hline & 100 & $97 \mathrm{ab}$ & $11.20 \mathrm{ab}$ & 9.13 & 11.66ab & $0.33 \mathrm{ab}$ & $0.9933 \mathrm{abc}$ \\
\hline & 10 & $98 \mathrm{ab}$ & $12.04 \mathrm{ab}$ & 11.97ab & $13.04 \mathrm{~b}$ & $0.00 \mathrm{ab}$ & $0.6667 \mathrm{abc}$ \\
\hline & 1 & $97 \mathrm{ab}$ & $11.64 \mathrm{ab}$ & $11.87 \mathrm{ab}$ & 15.22 & $0.00 \mathrm{ab}$ & $1.2333 \mathrm{abc}$ \\
\hline \multirow{5}{*}{$4 i$} & 1000 & $97 \mathrm{ab}$ & 11.29ab & 11.76ab & 10.79ab & $0.00 \mathrm{ab}$ & $1.3667 \mathrm{abc}$ \\
\hline & 500 & $100 \mathrm{ab}$ & $12.08 \mathrm{ab}$ & $12.29 \mathrm{ab}$ & 13.60 & $0.00 \mathrm{ab}$ & $1.1667 \mathrm{abc}$ \\
\hline & 100 & $100 \mathrm{ab}$ & 11.71ab & $12.43 \mathrm{ab}$ & 16.10 & $0.00 \mathrm{ab}$ & $1.1533 \mathrm{abc}$ \\
\hline & 10 & $99 \mathrm{ab}$ & $12.09 \mathrm{ab}$ & $12.66 \mathrm{ab}$ & 17.43 & $0.00 \mathrm{ab}$ & $1.2 \mathrm{abc}$ \\
\hline & 1 & $98 \mathrm{ab}$ & $12.09 \mathrm{ab}$ & $13.28 \mathrm{ab}$ & 17.58 & $0.00 \mathrm{ab}$ & $0.9667 \mathrm{abc}$ \\
\hline \multirow{3}{*}{ Control } & $\mathrm{H}_{2} \mathrm{O}$ & $99 \mathrm{a}$ & $12.33 \mathrm{a}$ & $11.85 \mathrm{a}$ & $11.26 \mathrm{a}$ & $0.33 \mathrm{a}$ & $0.5333 a$ \\
\hline & DCM & $100 \mathrm{~b}$ & $12.11 \mathrm{~b}$ & $13.01 \mathrm{~b}$ & $11.56 \mathrm{~b}$ & $0.57 \mathrm{~b}$ & $1.1 \mathrm{~b}$ \\
\hline & picloram (1000) & $67 \mathrm{c}$ & $3.63 \mathrm{c}$ & $0.46 \mathrm{c}$ & $3.73 \mathrm{c}$ & $7.27 \mathrm{c}$ & $0.7333 \mathrm{c}$ \\
\hline
\end{tabular}

G: percentage of germination; GSI: germination speed index; RG: root growth; MI: mitotic index; NA: frequency of nuclear alterations; CA: frequency of chromosomal alterations; DCM: dichloromethane. Means followed by the letter a represent water; means followed by the letter b represent DCM; and means followed by the letter c represent picloram; according to Dunnet's test $(p<0.05)$. 
cell division, such as the death of the nucleus rendering the initiation of prophase and consequently cell division difficult. $^{44,46}$

At the highest concentration, the triazoles promoted a reduction of dividing cells in lettuce root meristems. However, at lower concentrations, an increase in the percentage of dividing cells was observed compared with that in the controls (Table 1). Compounds $\mathbf{4 a}\left(1 \mu \mathrm{g} \mathrm{mL} \mathrm{m}^{-1}\right)$, 4b $\left(1 \mu \mathrm{g} \mathrm{mL} \mathrm{m}^{-1}\right), \mathbf{4 c}$ (1 and $\left.10 \mu \mathrm{g} \mathrm{mL}^{-1}\right), \mathbf{4 d}$ (1 and $\left.10 \mu \mathrm{g} \mathrm{mL}^{-1}\right), \mathbf{4 e}\left(1\right.$ and $\left.10 \mu \mathrm{g} \mathrm{mL}^{-1}\right), \mathbf{4 f}\left(1\right.$ and $\left.10 \mu \mathrm{g} \mathrm{mL}^{-1}\right)$, $\mathbf{4 g}\left(1 \mu \mathrm{g} \mathrm{mL}^{-1}\right)$, $4 \mathbf{h}\left(1 \mu \mathrm{g} \mathrm{mL} \mathrm{m}^{-1}\right)$, and $\mathbf{4 i}(1,10,100$, and $500 \mu \mathrm{g} \mathrm{mL}^{-1}$ ) positively influenced cell proliferation, with compound $4 \mathbf{i}$ especially resulting in a $56.12 \%$ increase of such activity.

An MI increase means that the number of cells undergoing mitotic division is increasing. If this increase is accompanied by an increase in the NA and CA percentages, it demonstrates chemical compound toxicity. Consequently, the daughter cells from these divisions will present alterations that may cause cell death and/or compromise the genetic integrity of subsequent generations of cells originating from these altered mother cells. ${ }^{37}$

With regard to the NAs (Table 1), only compound $\mathbf{4 a}$ at $1000 \mu \mathrm{g} \mathrm{mL}^{-1}$ showed a significant difference in frequency in relation to the controls. The other triazoles and treatments showed statistically similar frequencies to those of the respective negative controls (water and DCM).

For the CAs, there was a high frequency generated by compounds $\mathbf{4 a - 4 e}$, whereas the frequency generated by compounds $4 \mathbf{f}-\mathbf{4 i}$ was similar to that by both controls (positive and negative) (Table 1). The results were similar to those found in the investigation by Bernardes et al., ${ }^{47}$ in which the CA frequency was high after exposure of the seeds to difenoconazole, where broken chromosomes, C-metaphase cells, anaphase bridges, and polyploid metaphases were observed. In the present study, we also detected non-oriented, sticky, and delayed chromosomes, C-metaphase cells, and anaphase bridges (Figures 2 and 3).

All the evaluated compounds induced CAs (Figure 2), demonstrating an increasing effect with an increase in the compound concentration. The sticky chromosomes were the most expressive variable (Figure 3 ). This alteration may be related to the mechanism of aneugenic action caused by the interference of the triazole molecules with the mitotic spindle fibers, which impairs the chromosomal organization during metaphase and subsequently cell division, resulting in the daughter cells being different from the mother cell. ${ }^{48-50}$

Additionally, the presence of bridges, classified as a clastogenic alteration, was observed. These changes occur as a result of the breakdown of chromosomal end points, where the chromosomes consequently lose their stability. Thus, they bind to other chromosomes, giving rise to dicentric chromosomes that are pulled during segregation, forming a bridge between the cell poles. ${ }^{51,52}$

From the analyzed chromosomal changes, it is possible to infer the action mechanism of these triazoles; that is, it is related to the malfunction or non-polymerization of the mitotic spindle, as reported in the investigation by

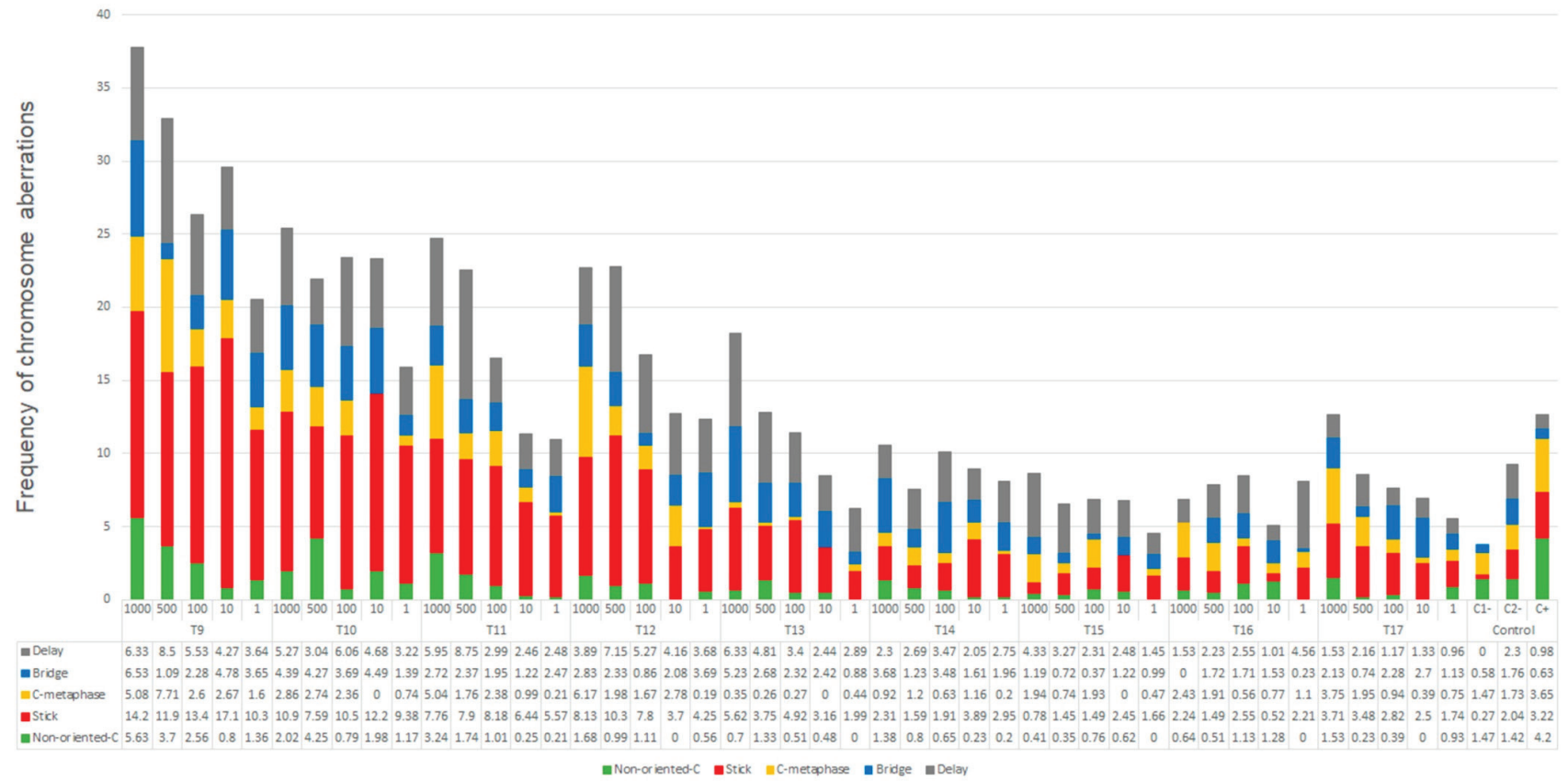

Figure 2. Chromosomal alterations (non-oriented-C, sticky, C-metaphase, bridge, and delay) observed in root meristematic cells of $L$. sativa exposed to the triazoles $\mathbf{4 a - 4 i}$. 




Figure 3. Chromosomal abnormalities observed in root meristematic cells of $L$. sativa exposed to the triazoles $4 \mathbf{a}-\mathbf{4 i}$. (a) Sticky chromosome, (b) c-metaphase, (c) anaphase bridge, and (d) non-oriented chromosome. Scale bar $=10 \mu \mathrm{m}$.

Costa et al. ${ }^{32}$ Depolymerizing substances are capable of inducing severe damage in the process of cell division, resulting in genetic alterations, which is classified as an aneugenic action. ${ }^{53}$

One of the significant alterations observed in this work was the presence of C-metaphase. This is caused by the complete inactivation of the cellular mitotic spindle, where no equatorial plate is mounted, consequently leading to the interruption of cell division ${ }^{54}$ and reinforcing the aneugenic mechanism of action of the triazoles.

The inhibitory activities of compounds $\mathbf{4 a}-\mathbf{4} \mathbf{i}$ toward the mycelial growth and sporulation of $C$. gloeosporioides are depicted in Table 2, along with regression models. All the triazoles investigated herein displayed inhibitory effects on $C$. gloesporioides growth in a dose-dependent manner.

Compounds $\mathbf{4 a - 4 i}$ showed a lower efficiency in inhibiting mycelial growth than the positive control tebuconazole, a commercial fungicide. As can be seen in Table 2, compounds $\mathbf{4 d}$ and $\mathbf{4 i}$ were the most active $\left(\mathrm{ED}_{50}\right.$ values below $20 \mathrm{ppm}$ ), with $\mathbf{4 i}$ being the derivative with the highest potency $\left(\mathrm{ED}_{50} 10.14 \mathrm{ppm}\right)$.

With regard to the inhibition of sporulation, all the 4-alkyl-substituted triazoles displayed considerable inhibitory effects $\left(E_{50}\right)$ that were comparable to that of tebuconazole. In particular, $\mathbf{4 e}$ was the most active, with an $\mathrm{ED}_{50}$ value lower than $0.00002 \mathrm{ppm}$.

On the basis of the $\mathrm{ED}_{50}$ values of the compounds (Table 2), it was possible to group them into different fungicidal classes. The group related to the efficiency of the compounds demonstrated the fungicidal action of the treatments. Similarly, the group related to sensitivity

Table 2. Mean mycelial growth and sporulation values of C. gloeosporioides treated with compounds $\mathbf{4 a - 4 i}$, and regression models

\begin{tabular}{|c|c|c|c|c|c|c|c|c|c|c|}
\hline \multirow[b]{2}{*}{ Compound } & \multicolumn{5}{|c|}{ Mycelial growth } & \multicolumn{5}{|c|}{ Sporulation } \\
\hline & Regression equation & $\begin{array}{c}\mathrm{ED}_{50} / \\
\mathrm{ppm}\end{array}$ & $\begin{array}{c}\mathrm{ED}_{100} / \\
\mathrm{ppm}\end{array}$ & $\begin{array}{l}\text { Effectiveness } \\
\text { (E) }\end{array}$ & $\begin{array}{l}\text { Sensitivity } \\
\text { (S) }\end{array}$ & Regression equation & $\begin{array}{c}\mathrm{ED}_{50} / \\
\mathrm{ppm}\end{array}$ & $\begin{array}{c}\mathrm{ED}_{100} / \\
\mathrm{ppm}\end{array}$ & $\begin{array}{l}\text { Effectiveness } \\
\text { (E) }\end{array}$ & $\begin{array}{l}\text { Sensitivity } \\
\text { (S) }\end{array}$ \\
\hline $4 a$ & $\begin{array}{c}\hat{\mathrm{Y}}=21.679+0.043 \mathrm{x}^{* *} \\
\mathrm{R}^{2}=0.99\end{array}$ & 661.69 & 1829.91 & $\mathrm{NE}$ & NS & $\begin{array}{c}\hat{\mathrm{Y}}=5.325+0.408 \log \mathrm{x}^{* * *} \\
\mathrm{R}^{2}=0.94\end{array}$ & 0.16 & 1023.94 & $\mathrm{HE}$ & HS \\
\hline $4 b$ & $\begin{array}{c}\hat{Y}=12.462+0.079 \mathrm{x}^{* *} \\
\mathrm{R}^{2}=0.99\end{array}$ & 471.86 & 1100.37 & $\mathrm{NE}$ & NS & $\begin{aligned} \hat{Y}=5.231 & +0.429 \log x^{* *} \\
R^{2} & =0.87\end{aligned}$ & 0.29 & 1016.99 & $\mathrm{HE}$ & HS \\
\hline $4 \mathrm{c}$ & $\begin{array}{c}\hat{\mathrm{Y}}=7.552+0.167-7.509 .10^{-5} \mathrm{x}^{2 * *} \\
\mathrm{R}^{2}=0.99\end{array}$ & 290.58 & 981.09 & $\mathrm{NE}$ & NS & $\begin{aligned} \hat{\mathrm{Y}}=5.298 & +0.567 \log \mathrm{x}^{* *} \\
\mathrm{R}^{2} & =0.95\end{aligned}$ & 0.29 & 800.18 & $\mathrm{HE}$ & HS \\
\hline $4 d$ & $\begin{array}{c}\hat{\mathrm{Y}}=3.588+1.214 \log x^{*} \\
\mathrm{R}^{2}=0.79\end{array}$ & 18.14 & 414.17 & $\mathrm{LE}$ & LS & $\begin{aligned} \hat{Y}=5.147 & +0.769 \log x^{* *} \\
R^{2}= & 0.93\end{aligned}$ & 0.64 & 400.09 & HE & HS \\
\hline $4 e$ & $\begin{array}{c}\hat{Y}=19.307+0.0312 x^{*} \\
R^{2}=0.70\end{array}$ & 984.07 & 2587.15 & $\mathrm{NE}$ & NS & $\begin{aligned} \hat{\mathrm{Y}}=5.930 & +0.193 \log \mathrm{x}^{* *} \\
\mathrm{R}^{2}= & 0.99\end{aligned}$ & 0.0002 & 1268.59 & $\mathrm{HE}$ & HS \\
\hline $4 f$ & $\begin{array}{c}\hat{\mathrm{Y}}=3.359+1.243 \log \mathrm{x}^{*} \\
\mathrm{R}^{2}=0.75\end{array}$ & 20.83 & 393.79 & LE & LS & $\begin{aligned} \hat{Y}=5.450 & +0.642 \log x^{* *} \\
R^{2} & =0.94\end{aligned}$ & 0.20 & 390.79 & $\mathrm{HE}$ & HS \\
\hline $4 \mathrm{~g}$ & $\begin{array}{c}\hat{Y}=27.934+0.069 x^{*} \\
R^{2}=0.69\end{array}$ & 319.79 & 1044.53 & $\mathrm{NE}$ & NS & $\begin{aligned} \hat{\mathrm{Y}}=5.548 & +0.298 \log \mathrm{x}^{* *} \\
\mathrm{R}^{2} & =0.95\end{aligned}$ & 0.01 & 1234.53 & $\mathrm{HE}$ & HS \\
\hline $4 h$ & $\begin{aligned} & \hat{Y}=5.153-0.684 x^{*} \\
& R^{2}= 0.72\end{aligned}$ & 25.71 & 858.59 & LE & LS & $\begin{aligned} \hat{Y}=5.215 & +0.701 \log x^{* *} \\
R^{2} & =0.91\end{aligned}$ & 0.49 & 556.78 & $\mathrm{HE}$ & HS \\
\hline $4 i$ & $\begin{array}{c}\hat{Y}=48.709+0.133 x-8.269 x^{2^{*}} \\
R^{2}=0.77\end{array}$ & 10.14 & 965.8 & LE & LS & $\begin{aligned} \hat{Y}=5.718 & +0.636 \log x^{* *} \\
R^{2} & =0.95\end{aligned}$ & 0.07 & 568.89 & $\mathrm{HE}$ & HS \\
\hline Tebuconazole & $\begin{aligned} \hat{\mathrm{Y}}=5.627 & +1.097 \log \mathrm{x}^{\mathrm{ns}} \\
\mathrm{R}^{2} & =0.55\end{aligned}$ & 0.26 & 35.32 & $\mathrm{HE}$ & HS & $\begin{array}{c}\hat{\mathrm{Y}}=6.598+0.640 \log \mathrm{x}^{2 * *} \\
\mathrm{R}^{2}=0.99\end{array}$ & $<1$ & 13.71 & $\mathrm{HE}$ & HS \\
\hline
\end{tabular}

$\mathrm{ED}_{50}$ : concentration of the active ingredient of the fungicide necessary to inhibit $50 \%$ of the mycelial growth and sporulation of the pathogen; $\mathrm{ED}_{100}:$ concentration of the active ingredient of the fungicide necessary to inhibit $100 \%$ of the mycelial growth and sporulation of the pathogen; E: effectiveness of fungicides; NE: not efficient; LE: low efficiency; HE: high efficiency; S: sensitivity of $C$. gloeosporioides to fungicides; NS: not sensitive; LS: low sensitivity; HS: high sensitivity; R²: coefficient of determination. Regression coefficient followed by $*$ or $* *$ are significant at the 5 or $1 \%$ probability, respectively; ns: not significant. 
allowed inference of the pathogenic resistance of C. gloeosporioides to the stress caused by the fungicides.

In terms of mycelial growth, three distinct groups could be distinguished; namely, high efficiency (HE), low efficiency (LE), and not efficient (NE). As expected, the activity of tebuconazole fell into the HE group. Even though compounds $\mathbf{4 d}$ and $\mathbf{4 i}$ were the most active, they were included in the LE group (along with compounds $\mathbf{4 f}$ and $\mathbf{4 h}$ ) because their activity was ca. 70 times (compound $\mathbf{4 d}$ ) and 39 times (compound $\mathbf{4 i}$ ) lower than that of tebuconazole. The triazoles $\mathbf{4 a}, \mathbf{4 b}, \mathbf{4 c}, \mathbf{4 e}$, and $\mathbf{4 g}$ fell in to the NE group.

With regard to the inhibitory effects on sporulation, tebuconazole and derivatives $\mathbf{4 a - 4 i}$ were highly efficient and formed the only HE group in Table 2.

The evaluation based on phenotypic expression is linked to the sensitivity of $C$. gloeosporioides to the studied compounds. The analysis of $\mathrm{ED}_{50}$ values for inhibition of mycelial growth also resulted in the identification of three distinct groups (HS: high sensitivity; LS: low sensitivity; NS: not sensitive). C. gloeosporioides was considered to be highly sensitive to the standard control tebuconazole only. However, in terms of the inhibition of sporulation, the fungus was highly sensitive to all the compounds investigated (Table 2), where there was no difference in the classification of treatments $\mathbf{4 a - 4 i}$ in relation to the tebuconazole control (all classified as $\mathrm{HS}$ ). The $\mathrm{ED}_{50}$ values within this group ranged between $0.00002(\mathbf{4 e})$ and $0.64 \mathrm{ppm}(\mathbf{4 d})$ for the triazolic derivatives.

The variations in the efficiency of the triazoles and the sensitivity of the fungal isolate to these derivatives, as observed in the present investigation, can be explained by the interaction of the molecules with their target site of action on the fungal species. Several factors can prevent the fungicide from reaching the target. Using Botrytis cinerea as a model, Kretschmer et al. ${ }^{55}$ demonstrated that the main mechanisms used by the fungus in response to fungicidal stress were alteration of the target site, fungicide detoxification, over expression of the target protein triggered by fungicide accumulation in the cell, and efflux of the fungicide from the target site.

A hypothesis that explains the variations in efficiency of the triazoles and the sensitivity of $C$. gloeosporioides in this work may involve the inhibition of the enzyme lanosterol $14 \alpha$-demethylase (CYP51). The triazoles are able to fit into the active site of CYP51 through hydrophobic interactions, hydrogen bonding, and $\pi-\pi$ stacking with the sextet binder of the heme group of the enzyme. As a result, the amount of ergosterol decreases and the accumulation of $14 \alpha$-demethylated sterols occurs, which disrupts the membrane structure and causes the death of the phytopathogen. ${ }^{56}$ Therefore, changes in the CYP51 gene could reduce the affinity of the triazoles to their target site of action on the fungal cell, or the over expression of CYP51 could increase the levels of sterol $14 \alpha$-demethylase in the fungus.

Another hypothesis, which does not exclude the former one, may be linked to an increase of triazole efflux due to positive regulation of the adenosine triphosphate (ATP)-binding cassette or major facilitator super family transporters in the membrane. ${ }^{57}$

\section{Conclusions}

By using the CuAAC reaction as the key step and glycerol as a starting material, a series of nine glycerolderived 4-alkyl-substituted 1,2,3-triazoles were synthesized in good yields and fully characterized. Compared with the commercial fungicide tebuconazole, all the compounds evaluated were highly efficient in inhibiting the sporulation of C. gloeosporioides, with $\mathrm{ED}_{50}$ values lower than $1 \mathrm{mg} \mathrm{L}^{-1}$. In addition, all the derivatives tested demonstrated aneugenic and clastogenic actions on meristematic cells of $L$. sativa roots. These glycerol-derived 1,2,3-triazoles may thus represent a novel scaffold to be exploited for the development of new active ingredients for fungus control.

\section{Supplementary Information}

Supplementary information IR, NMR $\left({ }^{1} \mathrm{H}\right.$ and $\left.{ }^{13} \mathrm{C}\right)$ and MS spectra of the compounds is available free of charge at http://jbcs.sbq.org.br as PDF file.

\section{Acknowledgments}

The authors are grateful to the following Brazilian agencies: Fundação de Amparo à Pesquisa e Inovação do Espírito Santo (FAPES), Conselho Nacional de Desenvolvimento Científico e Tecnológico (CNPq) and Coordenação de Aperfeiçoamento de Pessoal de Nível Superior (CAPES).

\section{References}

1. Arora, P.; Arora, V.; Lamba, H. S.; Wadhwa, D.; Int. J. Pharm. Sci. Res. 2012, 3, 2947.

2. Quin, L. D.; Tyrell, J. A.; Fundamentals of Heterocyclic Chemistry: Importance in Nature and in the Synthesis of Pharmaceuticals; John Willey \& Sons, Inc.: New Jersey, 2010.

3. Lamberth, C.; Pest Manage. Sci. 2013, 69, 1106.

4. Lopes, S. M. M.; Novais, J. S.; Costa, D. C. S.; Castro, H. C.; Figueiredo, M. S.; Ferreira, V. F.; Pinho e Melo, T. M. V. D.; Silva, F. C.; Eur. J. Med. Chem. 2018, 13, 1010. 
5. López-Rojas, P.; Janeczko, M.; Kubinski, K.; Amesty, A.; Mastyk, M.; Estévez-Braun, A.; Molecules 2018, 23, 199.

6. Sajja, Y.; Vonguru, S.; Jilla, L.; Vulupala, H. R.; Bantu, R.; Yogeswari, P.; Sriram, D.; Nagarapu, L.; Bioorg. Med. Chem. Lett. 2016, 26, 4292.

7. Tan, W.; Li, Q.; Wang, H.; Liu, Y.; Zhang, J.; Dong, F.; Guo, Z.; Carbohydr. Polym. 2016, 142, 1.

8. Shaikh, M. H.; Subhedara, D. D.; Khanb, F. A. K.; Sangshettib, J. N.; Shingatea, B. B.; Chin. Chem. Lett. 2016, 27, 295.

9. Petrova, K. T.; Potewar, T. M.; da-Silva, P. C.; Barros, M. T.; Calhelha, R. C.; Ćiric, A.; Soković, M.; Ferreira, I. C. F. R.; Carbohydr. Res. 2015, 417, 66.

10. Yamada, M.; Takahashi, T.; Hasegawa, M.; Matsumura, M.; Ono, K.; Fujimoto, R.; Kitamura, Y.; Murata, Y.; Kakusawa, N.; Tanaka, M.; Obata, T.; Fujiwara, Y.; Yasuike, S.; Bioorg. Med. Chem. Lett. 2018, 28, 152.

11. da Silva, F. C.; de Souza, M. C. B. V.; Frugulhetti, I. I. P.; Castro, H. C.; Souza, S. L. O.; de Souza, T. M. L.; Rodrigues, D. Q.; Souza, A. M. T.; Abreu, P. A.; Passamani, F.; Rodrigues, C. R.; Ferreira, V. F.; Eur. J. Med. Chem. 2009, 44, 373.

12. Jordão, A. K.; Ferreira, V. F.; Souza, T. M. L.; Faria, G. G. S.; Machado, V.; Abrantes, J. L.; Souza, M. C. B. V.; Cunha, A. C.; Med. Chem. 2011, 19, 1860.

13. Devender, N.; Gunjan, S.; Chhabra, S.; Singh, K.; Pasam, V. R.; Shukla, S. K.; Sharma, A.; Jaiswal, S.; Singh, S. K.; Kumar, Y.; Lal, J.; Trivedi, A. K.; Tripathi, R.; Tripathi, R. P.; Eur. J. Med. Chem. 2016, 109, 187.

14. Kumar, A.; Paliwal, D.; Saini, D.; Thakur, A.; Aggarwal, S.; Kaushik, D.; Eur. J. Med. Chem. 2014, 85, 147.

15. Teixeira, R. R.; Gazolla, P. A. R.; da Silva, A. M.; Borsodi, M. P. G.; Bergmann, B. R.; Ferreira, R. S.; Vaz, B. G.; Vasconcelos, G. A.; Lima, W. P.; Eur. J. Med. Chem. 2018, 146, 274.

16. Kamal, A.; Shankaraiah, N.; Devaiah, V.; Reddy, K. L.; Juvekar, A.; Sen, S.; Kurian, N.; Zingde, S.; Bioorg. Med. Chem. Lett. 2008, 18, 1468.

17. Colombano, G.; Traveli, C.; Galli, U.; Caldarelli, A.; Chini, M. G.; Canonico, P. L.; Sorba, G.; Bifulco, G.; Tron, G. C.; Genazzani, A. A.; J. Med. Chem. 2010, 53, 616.

18. Borgati, T. F.; Alves, R. B.; Teixeira, R. R.; de Freitas, R. P.; Perdigão, T. G.; da Silva, S. F.; dos Santos, A. P.; Bastidas, A. J. O.; J. Braz. Chem. Soc. 2013, 24, 953.

19. Agalave, S. G.; Maujan, S. R.; Pore, V. S.; Chem. - Asian J. 2011, 6, 2696.

20. Dheer, D.; Singh, V.; Shankar, R.; Bioorg. Chem. 2017, 71, 30.

21. Struthers, H.; Mindt, T. L.; Schibli, R.; Dalton Trans. 2010, 39 , 675.

22. Peiter, G. C.; Alves, H. J.; Sequinel, R.; Bautitz, I. R.; Rev. Bras. Energ. Renov. 2016, 5, 519.

23. Beatriz, A.; Araújo, Y. J. K.; de Lima, D. P.; Quim. Nova 2011, $34,306$.
24. https://www.chemicalsafetyfacts.org/glycerol/ accessed in October 2019.

25. Vivek, N.; Sindhu, R.; Madhavan, A.; Anju, A. J.; Castro, E.; Faraco, V.; Pandey, A.; Binod, P.; Bioresour. Technol. 2017, 239, 507.

26. Anitha, M.; Kamarudin, S. K.; Kofli, N. T.; Chem. Eng. J. 2016, $295,119$.

27. Bagheri, S.; Julkapli, N. M.; Yehye, W. A.; Renewable Sustainable Energy Rev. 2015, 41, 113.

28. Mota, C. J. A.; da Silva, C. X. A.; Gonçalves, L. C.; Quim. Nova 2009, 32, 639.

29. García, J. I.; García-Marína, H.; Piresa, E.; Green Chem. 2010 , 12,426 .

30. Gu, J.; Jérôme, F.; Green Chem. 2010, 12, 1127.

31. Ouyang, Y.; Yang, H.; Zhang, P.; Wang, Y.; Kaur, Y.; Zhu, Z.; Wang, Z.; Sun, Y.; Hong, W.; Ngeow, Y. F.; Wang, H.; Molecules 2017, 22, 1592

32. Costa, A. V.; de Oliveira, M. V. L.; Pinto, R. T.; Moreira, L. C.; Gomes, E. M. C.; de Assis Alves, T.; Pinheiro, P. F.; de Queiroz, V. T.; Vieira, L. F. A.; Teixeira, R. R.; Júnior, W. C. J.; Molecules 2017, 22, 1666.

33. Barbosa, L. C. A.; Pereira, U. A.; Maltha, C. R. A.; Teixeira, R. R.; Valente, V. M. M.; Ferreira, J. R. O.; Costa-Lotufo, L. V.; Moraes, M. O.; Pessoa, C.; Molecules 2010, 15, 5629.

34. Lima, L. S.; Barbosa, L. C. A.; de Alvarenga, E. S.; Demuner, A. J.; da Silva, A. A.; Aust. J. Chem. 2003, 56, 625.

35. Raja, M. R. C.; Velappan, A. B.; Chellappan, D.; Debnath, J.; Mahapatra, S. K.; Eur. J. Med. Chem. 2017, 139, 503.

36. Matoba, H.; Mizutani, T.; Nagano, K.; Hoshi, Y.; Uchiyama, H.; Hereditas 2007, 144, 235.

37. Pinheiro, P. F.; Costa, A. V.; Alves, T. A.; Galter, I. N.; Pinheiro, C. A.; Pereira, A. F.; Oliveira, C. M. R.; Praça-Fontes, M. M.; J. Agric. Food Chem. 2015, 63, 8981.

38. Montgomery, D. C.; Design and Analysis of Experiments, $5^{\text {th }}$ ed.; John Wiley: New York, 2001.

39. Cruz, C. D.; Acta Sci., Agron. 2013, 35, 271.

40. Edgington, L. V.; Khew, K. L.; Barron, G. L.; Phytopathology 1971, 61, 42 .

41. Rampersad, S. N.; Teelucksingh, L. D.; Plant Dis. 2012, 96, 1526.

42. R CORE TEAM-A Language and Environment for Statistical Computing; R Foundation for Statistical Computing, Vienna, 2016. Available at http://www.R-project.org/ accessed in October 2019.

43. Aragão, F. B.; Andrade-Vieira, L. F.; Ferreira, A.; Costa, A.V.; Queiroz, V. T.; Pinheiro, P. F.; Allelopathy J. 2015, 35, 259.

44. Aragão, F. B.; Queiroz, V. T.; Ferreira, A.; Costa, A. V.; Pinheiro, P. F.; Carrijio, T. T.; Andrade-Vieira, L. F.; Rev. Biol. Trop. 2017, $65,435$.

45. Taiz, L.; Zeiger, E.; Fisiologia Vegetal, $5^{\text {th }}$ ed.; Artmed: Porto Alegre, 2013 
46. Sousa, S. M.; Viccini, L. F.; Braz. J. Pharmacog. 2011, $21,98$.

47. Bernardes, P. M.; Andrade-Vieira, L. F.; Aragão, F. B.; Ferreira, A.; Ferreira, M. F. S.; Water, Air, Soil Pollut. 2015, 226, 207.

48. Andrade-Vieira, L. F. In Landfills: Waste Management, Regional Practices and Environmental Impacts, $1^{\text {st }}$ ed.; Cabral, G. B. C.; Botelho, B. A. E., eds.; Nova Science Publishers: New York, 2012, p. 319.

49. Andrade-Vieira, L. F.; Palmieri, L. J.; Botelho, C. M.; Luber, J.; Silva, M. F. F.; S. Afr. J. Bot. 2017, 113, 443.

50. Alves, T. A.; Pinheiro, P. F.; Praça-Fontes, M. M.; AndradeVieira, L. F.; Corrêa, K. B.; Alves, T. A.; da Cruz, F. A.; Lacerda Jr, V.; Ferreira, A.; Soares, T. C. B.; Ind. Crops Prod. 2018, 114, 59.

51. EL-Ghamery, A. A.; EL-Kholy, M. A.; EL-Yousser, M. A. A.; Mutat. Res. 2003, 53, 29.
52. Campos, J. M. S.; Davide, L. C.; Soares, G. L. G.; Viccini, L. F.; Allelopathy J. 2008, 1, 143.

53. Santos, F. E.; Carvalho, M. S. S.; Silveira, G. L.; Correa1, F. F.; Cardoso, M. G.; Andrade-Vieira, L. F.; Vilela, L. R.; Environ. Sci. Pollut. Res. 2018, 25, 1.

54. Fernandes, T. C. C.; Mazzeo, D. E. C.; Marin-Morales, M. A.; Ecotoxicol. Environ. Saf. 2009, 72, 1680.

55. Kretschmer, M.; Leroch, M.; Mosbach, A.; Walker, A.; Fillinger, S.; Mernke, D.; Schoonbeek, H.; Pradier, J.; Leroux, P.; Waard, M.; Hahn, M.; PLoS Pathog. 2009, 5, 12.

56. Price, C. L.; Parker, J. E.; Warrilow, G. S.; Kelly, D. E.; Kelly, S. L.; Pest Manage. Sci. 2015, 71, 1054.

57. Lerroux, P.; Walker, A. S.; Pest. Manage. Sci. 2011, 67, 44.

Submitted: June 21, 2019

Published online: October 16, 2019 